\title{
Effect of Blending Ratio on the Fuel Properties of Almond Biodiesel
}

\author{
Ejiro Thelma Akhihiero ${ }^{1 \star}$, Samuel Ogbeide Ebhodaghe ${ }^{1}$
}

${ }^{1}$ Department of Chemical Engineering University of Benin Edo State, NIGERIA

*Corresponding Author: thelma.akhihiero@uniben.edu

Citation: Akhihiero ET, Ebhodaghe SO. (2020). Effect of Blending Ratio on the Fuel Properties of Almond Biodiesel. European Journal of Sustainable Development Research, 4(3), em0119. https://doi.org/10.29333/ejosdr/7804

ARTICLE INFO

Received: 10 Nov. 2019

Accepted: 16 Jan. 2020

\begin{abstract}
Since almond seed oil can be used for biodiesel production, this study is aimed at investigating the effect of different blend ratios on the fuel properties of almond biodiesel. The biodiesel was characterized for the properties of flash point, cloud point, pour point, viscosity, saponification value, peroxide value, acid value, iodine value, density and specific gravity using the Gas Chromatography Mass Spectrophotometer (GCMS). When blended with petrol diesel at ratios of $20 \%, 30 \%$ and $50 \%$, results showed that the properties of the biodiesel obtained at a blend of $20 \%$ had properties more similar to the ASTM standard. At that proportion of $20 \%$, the properties of acid value, viscosity, cloud point, pour point and iodine value were found to be $0.95 \mathrm{meq} / \mathrm{kg}, 8.80 \mathrm{Cp}, 6^{\circ} \mathrm{C}, 1^{\circ} \mathrm{C}$ and $41.62 \mathrm{gl}_{2} / 100 \mathrm{~g}$ respectively, except the flash point which was $72^{\circ} \mathrm{C}$ at biodiesel blend of $50 \%$. This is because increase in blending ratios was found to result in corresponding increase of the properties.
\end{abstract}

Keywords: almond seed, biodiesel, blending ratio, fuel properties

\section{INTRODUCTION}

Almond seed oil has been investigated as a suitable source of biodiesel since it doesn't require the use of antioxidants or cold flow improver to meet biodiesel quality unlike most other vegetable oils (Kumar \& Sharma, 2015). Belonging to the Rosacea family, almond is a tree plant which can be found in Africa, Europe, North America and several parts of the Middle East (Fadhil \& Mohammed, 2016). Currently, fossil fuel usage accounts for $80 \%$ of total energy consumed globally (Suleman et al., 2015). This has resulted in adverse climate changes, greenhouse gas and other pollutants emission. However, research has shown that blending of vegetable oils with petrol diesel reduces the adverse effect of fossil fuel usage (Igbokwe et al., 2015; Khan et al., 2016).

Therefore, previous studies have investigated the effect of palm kernel oil biodiesel and its' blend with petrol diesel (Igbokwe et al., 2015), and performance emissions of blends of karanja and castor biodiesel with conventional diesel (Khan et al., 2016). More recently, the effect of hybrid rubber seed oil and babassu oil in a compression ignition engine was investigated (Varuvel et al., 2018). Several studies have shown little research attention on the effect of blending ratio on the biodiesel potential of vegetable oils. Some of these studies on almond seed oil have focused on the influence of co-solvent on its' yield and quality as well as determination of its' fuel properties (Fadhil \& Mohammed, 2016), production and optimization of biodiesel production (Al-Tikrity et al., 2017; Esonye et al., 2018) and its' applications in food, biotechnology and drilling operations (Oseh et al., 2019; Yesiloglu \& Baskurt, 2008).

Though recent studies have investigated the effect of blending ratios on the biodiesel properties of castor and sunflower biodiesel (Akhihiero et al., 2019; Singh \& Shukla, 2016), there is need for more research on other feedstock such as almond seed oil since it has been shown that almond oil is more suitable for biodiesel production due to the less time and cost required, than most vegetable oils which require substantial amount of antioxidants or cold flow improver to meet biodiesel quality (Kumar \& Sharma, 2015). To this end, this study is aimed at investigating the influence of blending ratio on the properties of almond biodiesel. A Gas Chromatography Mass Spectrophotometer (GCMS) will be used to determine the properties of the biodiesel.

\section{METHODOLOGY}

\section{Extraction of Almond Seed Oil}

Solvent extraction method was used to extract oil from Almond seed, using hexane as the extracting solvent and Soxhlet extractor as the extracting medium. 


\section{Production of Biodiesel}

A detailed procedure for the production process has been detailed in an earlier study (Akhihiero et al., 2013).

\section{Characterization of Biodiesel Blends}

The analysis was performed with Clarus 500 Gas Chromatography Mass Spectrophotometer. Samples were injected by a sampler injector at an oven temperature of 325 to $350^{\circ} \mathrm{C}$ for a total run time of 25 minutes.

\section{Determination of Oil Yield}

The percentage of Almond seed oil yield was calculated using the following equation

$$
\% \text { of oil yield }=\frac{\text { weight of oil }}{\text { weight of samplie on a dry basis }} \times 100
$$

\section{Determination of Density and Specific Gravity}

The density and specific gravity of the oil were determined using the density meter. The oil was injected using a syringe to the density bottle (Pycnometer) and the density meter was recorded for density and specific gravity of the oil at $40^{\circ} \mathrm{C}$.

\section{Determination of Acid Value}

The acid value was determined using the following equations:

$$
\text { Acid value }=\frac{56.1 \times V \times N}{M}
$$

Where $\mathrm{V}=$ Volume of the $\mathrm{KOH}$ solution used

$\mathrm{N}=$ Normality of $\mathrm{KOH}$

$\mathrm{m}=$ Mass of oil sample

\section{Determination of Saponification Value}

Saponification value which represents the number of milligrams of potassium hydroxide or sodium hydroxide required to saponify $1 \mathrm{~g}$ oil under the condition specified was determined using equation 3 :

$$
\text { Saponification value }=\frac{56.1 \times N \times(V 1-V 2)}{M}
$$

Where:

V1 = Volume in $\mathrm{ml}$. of Hydrochloric acid

$\mathrm{V} 2=$ Volume in $\mathrm{ml}$. of Hydrochloric acid

$\mathrm{N}=$ Normality of Hydrochloric acid

$M=$ Mass in gram of the oil

\section{Determination of Viscosity}

This was calculated using equation 4;

$$
\eta=\frac{\eta o \times p \times t}{p o \times t o}
$$

Where

no $=$ absolute viscosity of water

$P=$ density of the sample

$\mathrm{t}=$ time of flow of the sample

to $=$ time of flow of water

$P O=$ density of water at $40^{\circ} \mathrm{C}$

\section{Determination of Peroxide Value}

This was determined using the peroxide value representation given in equation 5 :

$$
\text { peroxide value }=\frac{(S-B) \times 0.1 \mathrm{~N} \times 1000}{\text { weight of sample }}
$$

Where, 


\section{ACID VALUE}

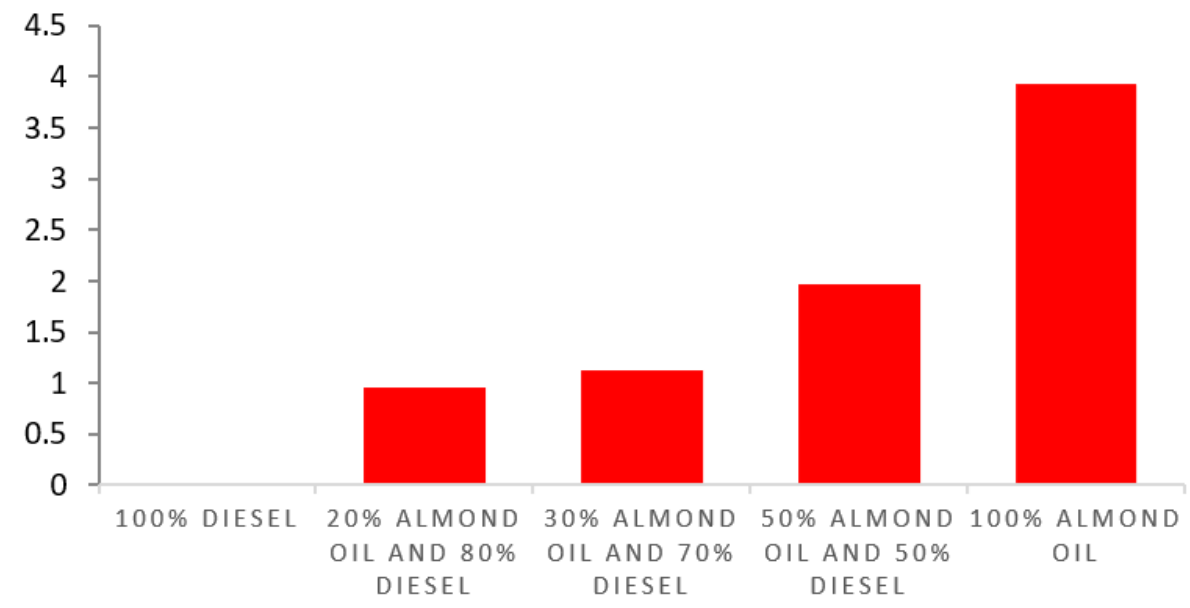

Figure 1. Effect of blend on acid value

$$
\begin{aligned}
& \mathrm{S}=\text { value of titre } \\
& \mathrm{B}=\text { value of blank } \\
& \mathrm{N}=\text { Normality }
\end{aligned}
$$

\section{Determination of Flash Point}

The flash point was determined using the Pensky-Marten apparatus which consists of a brass cup mounted in an air bath and heated by a gas flame.

\section{Determination of Cloud and Pour Point}

A cork carrying the test thermometer is used to close the jar. The thermometer bulb is positioned to rest at the bottom of the jar. The entire test subject is then placed in a constant temperature cooling bath on top of a gasket to prevent excessive cooling. At every $1^{\circ} \mathrm{C}$, the sample was taken out and examined for cloud and pour points, and then quickly replaced.

\section{Determination of lodine Number}

This was determined using the representation given in equation 6:

$$
\text { Iodine value }=\frac{(B-S) \times 0.1 \mathrm{~N} \times 12.69}{\text { weightofsample }}
$$

Where:

$B=$ Sodium Thiosulfate required $(\mathrm{mL})$

$\mathrm{S}=$ Sodium Thiosulfate required $(\mathrm{mL})$

$\mathrm{N}=$ Normality of Sodium Thiosulfate solution

\section{RESULTS AND DISCUSSION}

The result obtained for saponification value of the oil was $179.52 \mathrm{mgKOH} / \mathrm{g}$. This indicates that more alkali would be required to enable it neutralize the available free fatty acid liberated by the oil.

Figure 1 shows the acid value of the extracted almond biodiesel which is $3.9286 \mathrm{mgKOH} / \mathrm{g}$. Acid value increases as the percentage of almond seed oil biodiesel increased in the blends. The acid value of B20 is lowest while that of B100 is highest. The biodiesel blend of B20 implies a better biodiesel quality than other blend ratios because acid value determines the extent of rancidity. That is, exposure to atmospheric and oxidation effects. Low acid values as noted in blend B20 and diesel fuel can be attributed to the presence of antioxidants. The lower acid value in almond oil indicates that the oil will be stable over a long period of time and is protected from rancidity and oxidation effects.

The density and specific gravity of almond oil are shown in Table 1. The density increases as the percentage of almond biodiesel increased in the blends. The density value of B20 is very close to that of diesel fuel. This is very similar to the findings of Igbokwe et al 2015 (Igbokwe et al., 2015). 
Table 1. Comparison of almond biodiesel obtained in this study with other feedstock (Modified: El-Diwani et al., 2009)

\begin{tabular}{|c|c|c|c|c|c|c|}
\hline & $\begin{array}{c}\text { Almond oil } \\
\text { biodiesel }\end{array}$ & $\begin{array}{c}\text { Palm kernel oil } \\
\text { biodiesel }\end{array}$ & Castor biodiesel & $\begin{array}{c}\text { Dika nut } \\
\text { biodiesel }\end{array}$ & $\begin{array}{l}\text { Jatropha } \\
\text { biodiesel }\end{array}$ & $\begin{array}{l}\text { Sandbox } \\
\text { biodiesel }\end{array}$ \\
\hline Density $\left(\mathrm{g} / \mathrm{cm}^{3}\right)$ & 0.9 & 0.898 & 0.9268 & 0.910 & 0.8749 & 0.870 \\
\hline Viscosity (@40ㄷ, mm²/s) & 26.59 & 4.87 & 10.75 & 3.2 & 4.2 & 4.2 \\
\hline Flash point, ${ }^{0} \mathrm{C}$ & 212 & 171 & 190.7 & 140 & 167.5 & 156 \\
\hline Pour point, ${ }^{\circ} \mathrm{C}$ & 11 & -1.0 & -45 & -6 & -1 & 6 \\
\hline Cloud point, ${ }^{0} \mathrm{C}$ & 16 & 9.9 & -23 & -14 & -5 & 0 \\
\hline lodine value $\left(\mathrm{I}_{2} \mathrm{~g} / 100 \mathrm{~g}\right)$ & 76.65 & 140 & 85 & 90 & 95 & 127.5 \\
\hline
\end{tabular}

Table 2. Comparison of Characterized Almond Biodiesel with ASTM Standard

\begin{tabular}{|c|c|c|c|c|c|c|}
\hline \multirow{2}{*}{ Fuel Properties } & \multirow{2}{*}{ ASTM Diesel Standard } & \multicolumn{4}{|c|}{ Blend ratios } & \multirow{2}{*}{ Diesel Fuel } \\
\hline & & B20 & B30 & B50 & B100 & \\
\hline Acid value $(\mathrm{mgKOH} / \mathrm{g})$ & -- & 0.954 & 1.1224 & 1.964 & 3.9286 & 0.0267 \\
\hline 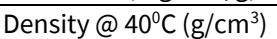 & $0.8 / 0.84$ & 0.832 & 0.840 & 0.8538 & 0.8950 & 0.825 \\
\hline Specific gravity @ 40ㄷ & -- & 0.8385 & 0.8466 & 0.8605 & 0.902 & 0.8315 \\
\hline Viscosity @ 40 C (Cp) & $2-5$ & 8.796 & 11.711 & 14.28 & 26.585 & 4.026 \\
\hline Cloud point, ${ }^{\circ} \mathrm{C}$ & -12 & 6 & 8.5 & 12 & 16 & -7 \\
\hline Flash point, ${ }^{\circ} \mathrm{C}$ & 65 & 66 & 69 & 72 & 212 & 63 \\
\hline Pour point, ${ }^{0} \mathrm{C}$ & -15 & 1 & 1.8 & 4.5 & 11 & -3 \\
\hline Iodine value $\left(\mathrm{I}_{2} \mathrm{~g} / \mathrm{100 \textrm {g }}\right)$ & $60-135$ & 41.623 & 52.029 & 63.196 & 76.65 & -- \\
\hline
\end{tabular}

\section{viscosity}

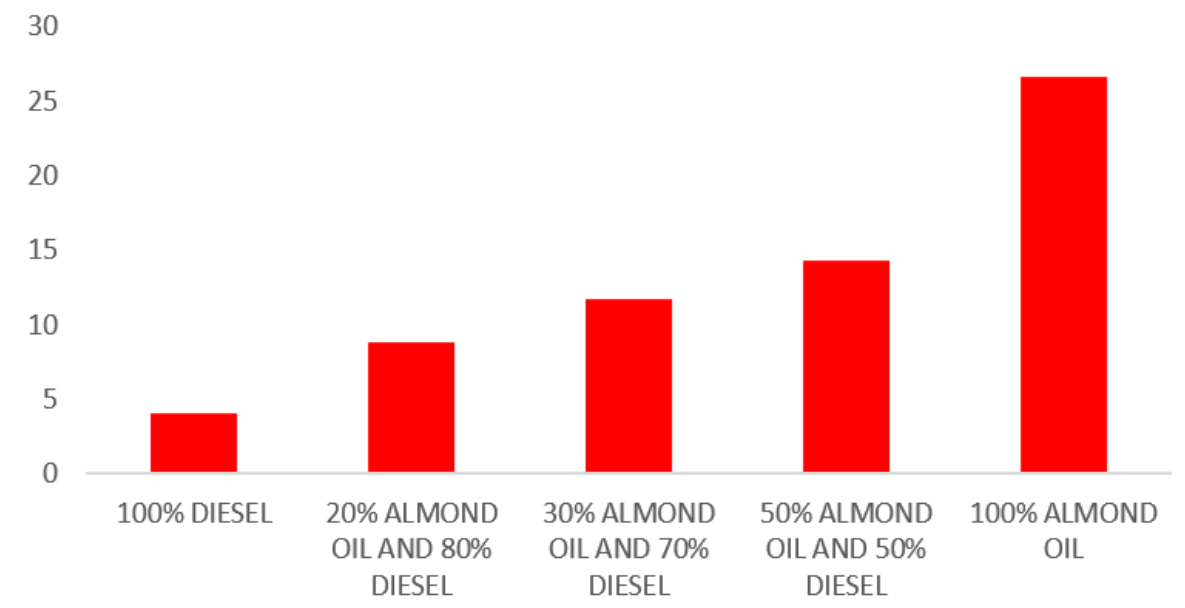

Figure 2. Effect of blend on viscosity

The viscosity of blend B100 is $26.585 \mathrm{Cp}$ while that of petrol diesel is $4.026 \mathrm{Cp}$ (Figure 2). Viscosity is pbserved to increase as the percentage of biodiesel in the blend increases. High viscosity values in biodiesel might be due to some unreacted triglycerides in the fuel (Igbokwe et al., 2015). This is not encouraged because viscosity affects operation equipment at low temperatures when increase in viscosity affects the fluidity of the fuel. Density also increases the viscosity of a liquid, the denser the liquid the more viscous it becomes.

The peroxide value of the oil obtained is $9.5 \mathrm{meq} / \mathrm{kg}$. The flash point, cloud point and pour point of the oil, diesel and blends are represented in Figure 3. The flash points of different blends of almond biodiesel are increased with increase in methyl ester content it is observed that the flash point of pure biodiesel is higher than that of petrol diesel (Igbokwe et al., 2015). This implies that pure biodiesels are safer for storage purpose, because the higher the flash points, the safer. Additionally, pour point of the almond oil was $11^{\circ} \mathrm{C}$ while that of diesel was $-3^{\circ} \mathrm{C}$. Pour point of the biodiesel and its' blends are within the ASTM standard range. As the percentage of biodiesel increased in the blends, the pour points of the various blends increased. This is similar to the findings of Igbokwe et al (2015). This result shows that when cooled to a temperature of $16.0^{\circ} \mathrm{C}$, the biodiesel sample forms a wax. With further temperature decrease to about $11^{\circ} \mathrm{C}$, the oil will stop flowing and become congealed.

The highest iodine value of the oil was $76.65 \mathrm{gl}_{2} / 100 \mathrm{~g}$ at B100 (Figure 4). High iodine value indicates an oil with good oxidative stability and implies good biodiesel properties (Eromosele et al., 1997). 
घ Cloud Point $\quad$ Pour Point Elash Point

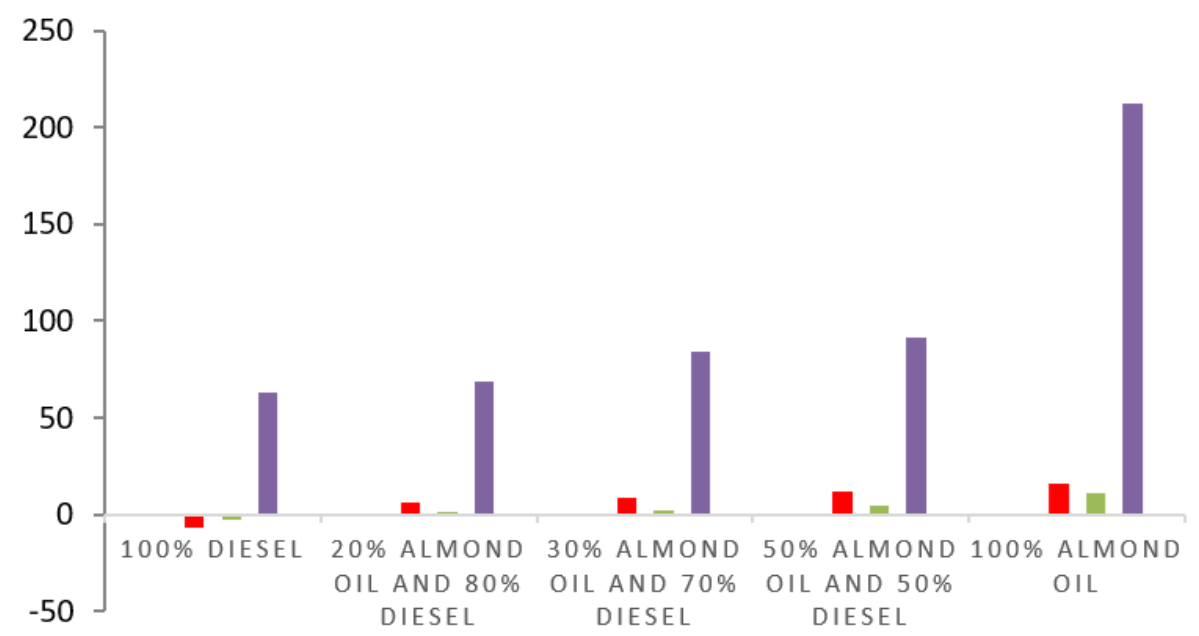

Figure 3. Effect of blend on Cloud, pour and flash points

\section{IODINE VALUE}

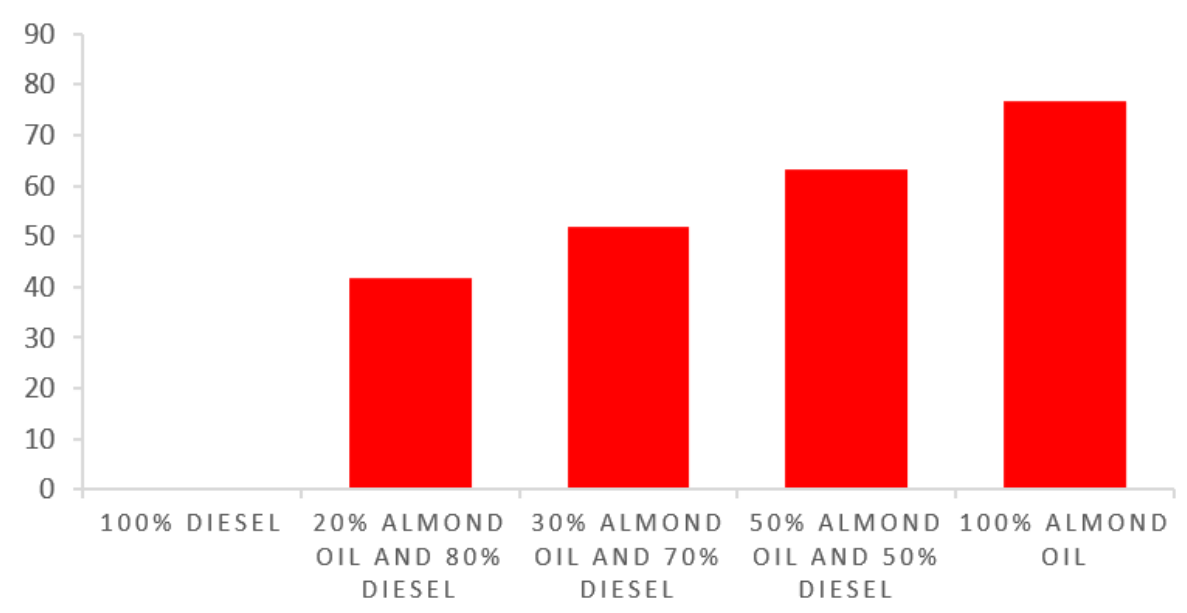

Figure 4. Effect of blend on lodine value

\section{CONCLUSION}

The effect of different blend ratios on the fuel properties of almond biodiesel has been investigated. At a biodiesel ratio of $20 \%$, the properties of acid value, viscosity, cloud point, pour point and iodine value were $0.95 \mathrm{meq} / \mathrm{kg}, 8.80 \mathrm{Cp}, 6^{\circ} \mathrm{C}, 1^{\circ} \mathrm{C}$ and $41.62 \mathrm{gl}_{2} / 100 \mathrm{~g}$ respectively, except the flash point which was $72^{\circ} \mathrm{C}$ at a blend of $50 \%$. These findings show that almond biodiesel exhibits improved fuel properties at a ratio of $20 \%$ with petrol diesel, when compared with other ratios. The properties were within ASTM standards and were similar to the findings of previous studies. One limitation in this study was that only few blending ratios were examined. Future studies can examine other blend ratios between $50 \%$ and $100 \%$ biodiesel. Besides, more attention can focus on the effect of environmental conditions on biodiesel properties of vegetable oils.

\section{REFERENCES}

Akhihiero, E. T., Aluyor, E. O., \& Audu, T. O. K. (2013). Effect of variation of temperature on the transesterification of jatropha seed oil using homogeneous catalyst. Journal of Advanced Material Research, 824, $473-476$. https://doi.org/10.4028/www.scientific.net/AMR824.473

Akhihiero, E. T., Omorewa, Y. G., \& Ebhodaghe, S. O. (2019). Effect of blending ratio on the properties of sunflower biodiesel. J. Mater. Environ. Sci., 10(10), 987-994.

Al-Tikrity, E. T. B, Fadhil, A. B., \& Ibraheem, K. K. (2017). Biodiesel production from bitter almond oil as new non-edible oil feedstock. Energy Sources, Part A: Recovery, Utilization and Environmental Effects, 39(7), 649-656. https://doi.org/10.1080/15567036.2016.1243172 
El-Diwani, G., Attai, N. K., \& Hawash, S. I. (2009). Development and evaluation of biodiesel fuel and byproducts from jatropha oil. Int. J. Environ. Sci. Technol., 6(2), 219-224.

Eromosele, C. O., Eromosele, P. I., \& Njerim, P. (1997). Short communication: studies on some seeds and seed oils. Bioresour. Technology, 64, 245-247.

Esonye, C., Onukwuli, O. D., \& Ofoefule, A. U. (2018). Optimization of methyl ester production from Prunus amygdalus seed oil using response surface methodology and artificial neural networks. Renewable Energy. https://doi.org/10.1016/j.renene.2018.06.036

Fadhil, A. B., \& Mohammed, H. M. (2016). Co-solvent transesterification of bitter almond oil into biodiesel: Optimization of variables and characterization of biodiesel. Transport, 33(3), 686-698. https://doi.org/10.3846/16484142.2018.1457568

Igbokwe, J. O., Nwufo, O. C., \& Nwaiwu, C. F. (2015). Effects of blends on the properties, performance and emission of palm kernel oil biodiesel. Biofuels. https://doi.org/10.1080/17597269.2015.1030719

Khan, K., Kumar, G., Sharma, A. K., Kumar, P. S., Mandal, C., \& Chintala, V. (2016). Performance and emission characteristics of a diesel engine using complementary blending of castor and karanja biodiesel. Biofuels, 9(1), 53-60. https://doi.org/10.1080/17597269.2016.1256552

Kumar, M., \& Sharma, M. P. (2015). Selection of potential oils for biodiesel production. Renewable and Sustainable Energy Reviews, 56, 1129-1138. https://doi.org/10.1016/j.rser.2015.12.032

Oseh, J. O., Mohd Norddin, M. N. A., Ismail, I., Ismail, A. R., Gbadamosi, A. O., Agi, A., \& Ogiriki, S. O. (2019). Investigating almond seed oil as potential biodiesel-based drilling mud. Journal of Petroleum Science and Engineering, 181. https://doi.org/10.1016/j.petrol.2019.106201

Singh, B., \& Shukla, S. K. (2016). Experimental analysis of combustion characteristics on a variable compression ratio engine fuelled with biodiesel (castor oil) and diesel blends. Biofuels, 5(5), 471-477. https://doi.org/10.1080/17597269.2016.1163210

Suleman, F., Dincer, I., \& Agelim-Chaab, M. (2015). Environmental impact assessment and comparison of some hydrogen production options. International Journal of Hydrogen Energy, 40, 6976-6987. https://doi.org/10.1016/j.ijhydene.2015.03.123

Varuvel, E. G., Subramanian, T., \& Khatri, P. (2018). Effect of diglyme addition on performance and emission characteristics of hybrid minor vegetable oil blends (rubber seed and babassu oil) in a tractor engine - an experimental study. Biofuels. https://doi.org/10.1080/17597269.2017.1418568

Yesiloglu, Y., \& Baskurt, L. (2008). Partial purification and characterization of almond seed lipase. Preparative Biochemistry and Biotechnology, 38, 397-410. https://doi.org/10.1080/10826060802325592 